\title{
Life-course influences on extended working: experiences of women in a UK baby-boom birth
}

cohort

\begin{abstract}
:
Combining feminist political economy and life-course perspectives, this mixed-methods study critically examines the extent to which extended working life policies take account of women's experiences of paid and unpaid work. I explore how decisions to extend working life are shaped by gendered social structures and norms across the life course among women in the Newcastle Thousand Families Study, a UK early baby-boom birth cohort. Among this cohort of women currently transitioning into retirement, analysis of longitudinal survey data identifies a range of mid- and laterlife factors that impact on the likelihood of women working beyond state-pension age. In-depth lifecourse interviews identify further complex and interacting gendered life-course experiences, not captured in the survey data, which act to necessitate, encourage, enable or constrain extended working. I conclude that, if women are to extend their working lives, 'joined-up' policies are required, addressing gendered inequalities across the life course.
\end{abstract}

Keywords: ageing workforce; baby boomers; birth cohort; extended working life; life course; mixed methods; older women; political economy; retirement

Josephine M. Wildman

Newcastle University, UK

Corresponding author: Josephine M. Wildman

Institute of Health and Society

Sir James Spence Institute

Royal Victoria Infirmary

Newcastle University

Newcastle upon Tyne NE1 4LP

Josephine.wildman@ncl.ac.uk 


\section{Introduction:}

This study captures the gendered life-course experiences that impact on women's decisions to extend their working lives (Krekula and Vickerstaff, 2017). Policies aimed at delaying retirement and extending working lives are being adopted across industrialised economies in response to population ageing. Yet, while much is known about retirement motivations, motivations to continue in employment remain under-explored (Taylor et al., 2016). This is especially true for women's employment (Hokema and Scherger, 2016). Despite large increases in the number of women in paid employment over the past decades (Office for National Statistics, 2019), the target of later-life employment policy discourse - and much research - is most often an individualised adult worker, assumed to have a traditionally male trajectory of a "full-time, full-year, full-life career" (Moen, 2011: 83). This "steady worker bias" (O'Rand, 1996: 235) fails to acknowledge the ways in which men and women's lives are distinct (Loretto and Vickerstaff, 2013, Moen and Roehling, 2005). To account for gendered influences on extended working, this study takes a feminist political-economy perspective to explore structural constraints that shape "the environment in which older women make work-life choices" (Ní Léime, 2017: 395). Moreover, political-economic landscapes are continually shifting. The life-course perspective provides an additional antidote to the homogenisation of the adult worker (Krekula and Vickerstaff, 2017), positioning the decision to extend working life as a function of life-long interactions between individual lives and ever-changing institutions and social norms (Scherger, 2015). This mixed-methods study explores the impact of lifecourse circumstances on women's later-life employment decisions using data from the Newcastle Thousand Families Study (NTFS) (Pearce et al., 2009), a birth cohort now in its eighth decade. The NTFS cohort is among the early wave of the UK's post-World War II 'baby boom', which occurred between 1945 and 1954. Baby-boomer women are the first generation of women to be entering later life in paid work in large numbers. Women's relationship with the labour force has undergone huge changes over these women's life course and there is a need for research into the ways in which 'boomers' are "navigating contemporary work and retirement pathways" (Kojala and Moen, 2016: 
60, Karpen, 2016). Differing policy contexts mean that structures that enable choice - such as pension provision (Ní Léime and Loretto, 2017) or the nature of women's employment (Lain, 2016) vary between countries (Dingemans et al., 2016). Much of the limited research into later-life economic activity among baby-boomer women comes from the US and Australia and this article adds to limited knowledge of women's experiences of work and retirement in a UK politicaleconomy context.

To-date, few studies in this area have combined sources of qualitative and quantitative data (Duberley and Carmichael (2016) is an exception) and this study's mixed-methods approach allows a comprehensive understanding of the phenomenon of women's extend working. Carpentieri and Elliot (2014) advocate a mixed-methods approach to explore narratives among cohort study members, distinguishing between the key structuring elements recorded in quantitative data and insights into experiences of daily life and their meanings captured by in-depth interviews (Carpentieri and Elliot, 2014). Prospective longitudinal quantitative survey data are used here to model life-course factors associated with women's $(n=199)$ paid employment beyond state-pension age. Taylor et al. (2016: 685) argue that to-date there has been "a lack of attention to older workers as people" situated within particular work and family contexts, advocating for "more qualitative approaches to test, explore and interpret quantitative findings". Qualitative interviews with a subsample of the NTFS cohort's women $(n=14)$ - the first to be conducted with members of this cohort explores in greater depth, and in their own words, how life-course experiences of paid and unpaid work influenced the 'choice' to remain in employment in later life. The study findings contribute to knowledge of women's extended working by highlighting the importance of taking a whole-life approach to explore legacies of the past (Wiggins et al., 2004): the quantitative analysis identifies a range of both mid- and later-life factors, among this cohort of women currently transitioning into retirement, which impact on the likelihood of working beyond state-pension age. Interview narratives identify further complex and interacting gendered life-course experiences, not captured in 
the survey data, which act to necessitate, encourage, enable or constrain extended working. These findings militate against the assumption that women are free to choose whether (or not) they extend their working lives. The conclusion observes that, as many of the life-course challenges faced by these women persist, there is much their experiences can tell us about the drivers and constraints to extended working facing women

\section{Theorizing women's extended working}

A review of the evidence identifies four main factors as influencing post-retirement employment: financial necessity, caring responsibilities, social networks and the availability of flexible work (Flynn, 2010). Scherger (2015) suggests a model that captures the interplay of agency and structure underpinning these factors: an individual might decide to extend employment for intrinsic reasons (for example, to maintain their social network) and/or for extrinsic reasons (for example, financial necessity). Decision-making might be enabled or constrained by an individual's ability to undertake paid work (for example, dependent on adequate health, skills or caring commitments) and/or by the availability of suitable paid work (Scherger, 2015). Feminist scholars argue that gendered economic, political, organisational and social structures exert further influence on all aspects of this model (Ní Léime and Loretto, 2017, Ní Léime, 2017). Baby-boomer women have lived through fundamental structural and social changes that rapidly altered women's relationship to the labour market. Over the past decades, labour-force composition has changed significantly. The proportion of women in employment in the UK has increased from less than 50 percent in the 1950 s to over three-quarters currently (Office for National Statistics, 2019), driven, in part, by legislative changes, such as the 1975 Sex Discrimination and the Employment Protection Acts, which protected women's rights in the workplace (Office for National Statistics, 2013). The occupational structure of the labour force has also shifted. The workplace 'gender revolution' was driven by an increase in the number of service sector jobs - most often occupied by women - in developed economies and the decrease in the number of manufacturing jobs (most often occupied by men). In 1962 (the year many in this 
cohort entered the workforce), the service sector accounted for less than half of UK employment (Court, 1995). In 2018 over 80 percent of jobs were in this sector (Office for National Statistics, 2019). The past 30 years have also seen an increase in the number of women in professional and managerial jobs driven largely by rapidly-expanding opportunities in the health and education sectors (Court, 1995).

However, although at the vanguard of the 'gender revolution', baby-boomer women faced challenges entering and remaining in the labour force. This cohort's women entered the labour market from the early 1960s, an era when 'normal' life for women was marriage and motherhood (Holloway, 2005). Because girls in this cohort were destined for domesticity, early NTFS research noted that many parents considered a daughter's education to be far less important than a son's (Miller et al., 1974). Upon leaving school, young baby-boom women entered a labour market set up for men, with no entitlement to maternity pay or protection. Illustrating how far working mothers deviated from contemporary social norms, a mother in full-time employment was one of the six criteria for a child's "unsatisfactory care" in the original NTFS (Spence et al., 1954: 126). The modified breadwinner model of combining paid employment with un-paid caring was the norm for baby-boomer women (Loretto and Vickerstaff, 2013). McCarthy (2016) notes that a number of contemporary feminist sociologists described a 'dual role' for women (as part-time workers and family carers) as a mechanism for balancing the needs of the family and the economy. The dual role meant that part-time employment was the dominant model of women's labour-force engagement (Lain, 2016). Finally, even for the same work, women's labour was valued at less than men's: in 1997 - when the 1947 baby-boom cohort was aged 50 and in their peak earning years - the gender pay gap was over 17 percentage points (Office for National Statistics, 2014).

Gendered experiences of employment and caring in earlier life have implications for later-life employment. Life-course caring commitments compel some women to remain in employment 
through financial necessity (Finch, 2014, Lain, 2015): mothers work later on average than childless women, in part due to a motherhood pay penalty that impacts on their ability to financially prepare for retirement (Hank and Korbmacher, 2012). There is mixed evidence for the effect of later-life caring responsibilities (for example, for ageing parents) on women's extended working. Some studies find caring strongly predicts women's exit from paid work (Byles et al., 2013, Jacobs et al., 2014); others find that, perhaps because women become accustomed to combining paid work and caring, caring responsibilities have a significant positive effect on men's early retirement but not on women's (De Preter et al., 2013). However, it remains the case that older women whose employment plans are "blown off course" by caring commitments are at particular risk of having an inadequate later-life income (Vickerstaff, 2006: 467). Gendered employment and caring regimes interact with the pension system to women's further disadvantage (Ginn et al., 2001, Ní Léime and Street, 2017). Low-pay and disrupted work histories mean that women in the UK have, on average, lower state pension entitlements than men (Thurley et al., 2018). Because the UK state pension is ungenerous, individuals without private or occupational pension income are at risk of poverty in older age (OECD, 2017). This is a particular risk for women who are more likely than men to have no or low levels of private pension wealth (Thurley et al., 2018). The pension gap may, in part, explain why women in the UK are more likely than men to work beyond state-pension age (Finch, 2014).

Economic and social structures such as occupational and relationship status create within-gender differences in women's retirement experiences (Karpen, 2016). Retirement is often a joint decisionmaking process (Loretto and Vickerstaff, 2013) and a large positive effect of a working partner on continued employment among older women has been identified (Lain, 2016). Previous research on women's extended working focuses on married women; however, non-married women are likely to face different challenges. Divorce rates increased sharply among this cohort: 12 percent of women born in 1947 are divorced compared to only three percent of women born in 1921 (Office for National Statistics, 2018). Because many women rely on a partner's pension income to enable their 
work exit, divorced women and single women with children are more likely than married or childless single women to extend their working lives (Finch, 2014, Pleau and Shauman, 2013). The extent to which extended employment is chosen or necessitated and enabled or constrained is also heavily influenced by socioeconomic advantage (Vickerstaff and Cox, 2005, Beehr et al., 2000). Research into the experiences of baby-boom women tends to focus on upper- and middle-class women, whose retirements are most likely to resemble those of men: from full-time professional employment to full-time retirement funded by their own pensions (Karpen, 2016). By including women from across the socioeconomic and relationship spectrums, this present study adds to knowledge of the experiences of less socially-advantaged and not-married women.

\section{Research design and method}

\section{The Newcastle Thousand Families Study}

This study uses data from the Newcastle Thousand Families Study, a longitudinal birth-cohort study based in Newcastle upon Tyne, a city in north-east England. The cohort originally comprised 1142 infants born between May and June 1947 to mothers living within the city boundaries. Originally followed until the end of compulsory education at age 15 , the cohort was re-contacted as it approached age 50, resulting in a major follow-up ( $n=574$ ) carried out between 1997 and 1999 (at age 49-51). A second follow-up ( $n=437$ ) was conducted between 2009 and 2011 (at age 62-64). In both follow-ups, respondents returned a lengthy questionnaire, including health, social, educational and occupational histories. The 2009-11 questionnaire also collected data on retirement. The availability of prospective data collected in mid-life allows exploration of associations free from recall bias. To-date, data from the NTFS cohort has been used mainly in epidemiological studies; this study is among the first sociological treatments of the data (see also Wildman et al., 2018). 


\section{Mixed-methods research design}

Logistic regression analysis of survey data can identify and parameterise the phenomenon of interest (women who extend their working lives beyond state-pension age) and model the effects on the likelihood of extended employment of a range of potential associates. Findings from the analysis of data collected through life-course narratives with a cohort sub-sample reveals factors in individual lives that are perhaps missing or inadequately captured in the survey data (Carpentieri and Elliot, 2014).

\section{Quantitative Data and methods}

\section{Dependent variable}

Self-reported employment status at age $62-64$ is used as a measure of extended employment. At the time of the 2009-11 NTFS survey, UK state-pension age was 60 for women; therefore, women in employment at ages 62-64 would be considered to be working 'late' (post-state-pension age).

\section{Independent variables}

The NTFS surveys contain a range of variables previously identified as life-course antecedents of retirement or later-life employment. These include variables measured in the 1997-99 survey (when the cohort was aged 49-51) that represent health, household social class, marital status and occupational status. Variables measured in the 2009-11 survey (when the cohort was aged 62-64) include measures of wealth (represented by home-ownership status as occupational social class is likely to have less relevance in later life), pension income, spouse or partner's occupational status, motherhood and the presence of a surviving parent.

The sample for analysis is restricted to individuals with a complete set of observations ( $n=199)$. A descriptive analysis of the characteristics of the quantitative sample is reported in Table 2. A multivariable model is estimated using binary logistic regression due to the dichotomous nature of the dependent variable. Average partial effect sizes and their $95 \%$ confidence intervals (Cls) are calculated for factors associated with women's employment at age 62-64. Average partial effects are 
reported to aid comparisons of the effect size of each predictor and to highlight variables that may have an important effect size but may be non-significant due to the relatively small sample size.

\section{Qualitative data and methods}

In 2016, when the NFTS cohort was aged 67/68, in-depth interviews with a sub-sample of the cohort ( $n=27$, including 14 women) were conducted to explore life-course influences on retirement, health and well-being in early old age. Ethical approval for the interviews was granted by Newcastle University Faculty of Medical Sciences ethics committee. Cohort members' information is stored within a database in which names and contact details are stored separately from other information. Each study member has a unique numeric identifier enabling linkage between different aspects of the database. Parameters of interest (mid- and later-life employment status, mid-life social class, mid- and later-life relationship status and motherhood status) were identified in the database, enabling identification of criteria for sampling participants. Due to financial constraints, sampling was confined to cohort members living in north-east England. Potential participants were contacted by post and provided with an information sheet, outlining the study aims and methods and risks and benefits of participation. Invitations were sent to 23 women and 11 agreed to participate. Three women who were married to men in the NTFS cohort (who were interviewed as part of the larger study) elected to participate in interviews bringing the total number of women interviewed to 14 . Following informed consent, interviews, conducted by the author, took place in participants' homes and lasted between 60 and 150 minutes. They were guided, where necessary, by a semi-structured interview schedule. However, participants were encouraged to provide a narrative that encompassed their lives since leaving school. Transcription of interviews was conducted by the author, enabling increased familiarity with the data. A thematic analysis was undertaken. An initial coding scheme developed and indexing undertaken through constant comparison within and between cases (Green and Thorogood, 2014). Categories were developed and refined iteratively with reference to the quantitative findings. Names used in this article are pseudonyms. 
Table 1 gives details of the interview participants. State pension age was 60 for this cohort's women. Nine women had been in paid work at age 62-64, three were retired and two reported their status as caring for home and family. Participants' self-defined retirement ages ranged between 50 and 66 years and represented a wide variety of experiences: working beyond age 60 before retiring; early retirement followed by an immediate return to work; notionally retiring at age 60 while continuing to work in the same job; or continuing a caring role both before and after a barely registered 'retirement'. Three women were still in part-time employment at age 67/68 (at the time of interview).

[TABLE 1 here]

\section{Findings}

Women's work

Interview participants were aware of their positon at the vanguard of the 'gender revolution', differentiating between their generation and that of their mothers who were from "that generation" (Lucy) of women who had lived in 'a different world [where] they didn't employ married women' (Susan). However, experiences of women in this study suggested that social change was evolutionary rather than revolutionary. Participants' relationships with work, inside and outside the home, had been structured along gender lines from a very early age. Reflecting the assumption that they would perform a home-maker role, the type of employment that girls could aspire to was usually lowerpaid and lower-status 'women's work'. Clare had encountered typically limited options: 'at school I took a clerical course because the understanding was that I was just going into an office and maybe become a secretary or something like that'. Similarly, as a young woman Lynne had been denied her first choice employment in the armed forces. She described how she had settled on a 'suitable' career: 
'I was told, no, they don't take women ... so I thought, "well which routes can I take?" And I thought the only routes: air hostess, and I'm glad I didn't, 'cos it's a bloody awful job! [Laughing] Then they suggested nurse. I went into teaching because that was the accessible way [to achieve a career], that was achievable.'

Social norms placed women in the home and all but one of the interview participants had careers disrupted by caring responsibilities. Women in this early baby-boom cohort entered the workforce at a time when formal childcare was rare with state-provided services only for those who met certain limited criteria (Lewis, 2013). Clare recalled 'a culture' where 'you looked after your children and you were at home'. Women described a labour market hostile towards working mothers. Although no longer widely formalised, the spirit of the 'marriage bar', which meant that upon marriage women had to leave the labour force (Holloway, 2005), persisted. Alice recalled: 'I went back to work, that was frowned on ... you couldn't keep your job, you had to leave ... no matter what your circumstances, if you were having a baby, "Leave"'.

Yet, despite the challenges of entering and remaining in employment, the majority of NTFS women undertook paid work to varying degrees across the life course. At age 50, fewer than 20 percent of women in the quantitative sample were economically inactive and over 40 percent were in full-time employment (Table 2). Table 2 reports results of the multivariable logistic regression analysis of factors associated with women's employment at age 62-64. The quantitative data indicated a strong relationship between mid-life labour force attachment and employment beyond state pension age. Economic inactivity in mid-life (compared to full-time employment) was associated with a 27 percentage-point decrease in the likelihood of paid employment at age 62-64. Part-time employment in mid-life was also negatively associated (but with a smaller effect size) with later-life employment.

[TABLE 2 here] 
'I had to earn': employment as a necessity

Analysis of both data sets allowed interrogation of reasons for the association between mid-and later-life employment. While women's work has long been considered secondary to men's, viewed as a source of 'pin-money', women's wages have always supported their families (Moen and Roehling, 2005). The quantitative data suggested evidence of extended employment due to financial necessity, with a mortgage at age 62-64 significantly increasing a woman's chances of working at this age (Table 2). Interview data supported the notion that the need to earn money was a powerful motivation for paid work. A range of life-course transitions, such as a partner's ill-health or unemployment, had altered the centrality of paid work in participants' lives - some of whom became the main or sole family breadwinner. Three women's husbands had suffered multiple, lengthy spells of unemployment, beginning in the 1980s when UK cities like Newcastle upon Tyne rapidly deindustrialised, resulting in devastating job losses among working-class men. Women like Judith had worked to provide for their families:

'I worked till I was nine-months' pregnant, 'cos [husband] was out of work then ... [son] was born three weeks' later, and six weeks after that, I went back and I said, "Could I come back to work part-time? We need the money".'

Destabilising transitions had created a desire for financial security among some women. Ann's husband's lengthy spells of unemployment convinced her of the necessity of providing for herself. She had chosen to pay the National Insurance Contributions required for a full state pension rather than the reduced married women's 'stamp', explaining: 'you've got your own money like that ... I've always had my own money'. Sarah's husband's poor health had created a sense of financial precariousness: 'that's why I was striving in my job, to be able to support my children, 'cos I always thought I'd be on my own'. As family bread-winners, lone mothers simply 'had to earn' (Lynne). Single mother Jennifer had '... always supported myself, l've never had anything from anyone ... I've 
never had maintenance for the children, or anything, so I've always just had my income, I've always just looked after me and my two children'.

As in earlier life, later-life employment was also motivated by financial necessity. The weak association between pension scheme contributions and extended working found in the quantitative data (Table 2) may reflect the small role that non-state pension income played in women's decision making. Interview narratives captured the intersection of gendered caring norms and social class that impacted on women's ability to financially prepare for retirement. Some women had never had the opportunity to accrue even low levels of private or employers' pension savings. While the increased availability of flexible work (usually represented by part-time hours) enabled many women to combine caring responsibilities with paid employment, in later-life the opportunity-costs could be heavy. After a period as a stay-at-home widowed mother, Clare (still working one day a week at age 67) had taken semi-skilled employment that fitted around childcare, meaning she 'wasn't in a position to prepare for a retirement'. She had relied on her state pension to enable her to reduce her full-time work to part-time: 'I couldn't afford to do it otherwise, if I wasn't getting a pension I would have just kept on working'. Low-paid work, childcare responsibilities and a husband who experienced long-term unemployment had resulted in a 'triple jeopardy' for Emma. She had taken part-time work when her children were young and her hours had been too few and her earnings too low to pay the National Insurance Contributions required for eligibility for anything above a fraction of the basic state pension. After 25 years with the same employer, she was entitled to only ' $a$ pittance' of a state pension of less than $€ 70(\$ 91, € 80)$ a week. III-health had forced Emma's early retirement at age 53 and she and her husband were struggling on a low income.

Low wages mean that women often rely on a husband's income to enable their retirement (Phillipson and Smith, 2005). The quantitative data supported the importance of relationships in enabling women's retirement. Divorce (or widowhood) in mid-life was associated with an 18 
percentage-point increase in the likelihood paid employment at age 62-64 (Table 2). Women with no partner at age 62-64 also had a significantly increased likelihood of being in employment at this age. Divorced, widowed or single participants spoke of the financial challenges posed by retirement. Having begun her professional career in her late thirties, never-married Jennifer had contributed to her occupational pension scheme for a little over twenty years and remained working beyond statepension age, in part, to provide herself with an adequate retirement income. She described her uncertainty around retiring on one pension: 'suddenly, when I wasn't earning money, I did think, "gulp", you know? When you've only got yourself?'

\section{'A full-time person': employment as a choice}

While, across the life course, financial necessity played a large role in women's employment, for participants who had extended their working lives paid work also provided intrinsic benefits and "great rewards" (Sarah, ceased employment at age 64), including "commitment", "responsibility" (Lucy, ceased employment at age 65), social contact and a sense of "belonging" (Jennifer, ceased employment at age 64). The 'worker' role was an integral part of many of the women's identities. Lengthy work histories engendered satisfaction and pride in women in all types of work, with having "worked all my life" (Sarah, professional work) a measure of success. Sally (semi-skilled work) felt she had earned her retirement at age 66: 'all the taxes I've paid and everything like that, I think I've kept the country long enough'. Extended working was chosen by women with high work centrality and, for some, giving up employment had been emotionally challenging. Few had retired willingly, with poor health, redundancy and work-place restructuring cited as reasons for work exit. The language of bereavement was used to describe leaving employment: retirement at age 64 left Sarah "grieving for my career, 'cos I had a good career". Paid work allows location within a social hierarchy (Fasbender et al., 2015) and status maintenance provided a motivation for extended employment. Alice vividly compared the status loss accompanying what she termed "'voluntary' redundancy- 
slash - retirement" from her career job at age 50 with the loss of status accompanying leaving work to care for children:

'Just coming out of working full-time, being a full-time person, people do like to know what you do, because they then think, "Oh, right, well she's about there" [indicates a level around chest height] ... and you feel you can get to grips with people ... and I suppose it's like that when you leave work to have children, and you've had a responsible position, and now you're just somebody's mam, and you miss the status, the little bit of status that you feel you've got, and you have got, and you've worked towards getting that, and it's just - flop - it's gone.'

Alice was still in part-time employment at age 68 , with no plans to stop.

\section{No choice}

While many women who extended their employment beyond state pension age expressed a strong attachment to paid work - through choice and/or necessity, for others employment status was an inadequate measure of work attachment. Whatever the motivation, extending working life depends upon an individual's ability to undertake employment (Scherger, 2015). As in earlier life, later-life caring responsibilities could severely constrain women's ability to undertake employment. Catherine had to give up full-time paid work to care, unpaid, for her adult son who had disabilities. She powerfully described the intrinsic and extrinsic losses accompanying her work exit:

'II felt as if the rug had been pulled out from under me. I knew it was going to happen at some point. I didn't know when it was going to happen and how it would feel. I was lost, really lost. I mean, you miss the friends, you miss everything that goes on, it was a busy, busy place. You miss the customers, the company, everything about it [and] you do miss a salary 
like that, and then to go onto a Carers' [Allowance] ... I think it was about thirty pound at the time, the carers' money. So you lose hundreds, and then end up with thirty pound a week and you think, "Oh!" ... but, it was for [my son] and I did it.'

Catherine's withdrawal from employment was not indicative of weak work-attachment and serves as a reminder that categorising women according to 'preferences' for work or family over-emphasises choice and downplays constraints (Walters, 2005).

Finally, while frequently treated as such, extended working is rarely an individual decision (Loretto and Vickerstaff, 2013). Supporting previous studies that found evidence of joint-decision making, in the quantitative analysis a spouse or partner in paid employment was associated with a 34 percentage-point increase in the likelihood of a woman working at age 62-64 (Table 2). There are likely to be a range of explanations for this association: joint-working may reflect financial necessity, alternatively, it may reflect high levels of work centrality. Spousal pressure to retire may also play a role (Henkens, 1999). Although her husband was keen to retire from his demanding job, Lucy was far more ambivalent about 'retiring' from her career job at age 50:

I hadn't actually intended to retire ... it was quite a big decision, actually, to stop the good job I was doing. I wouldn't say I was absolutely ready to stop, I would have gone on but I know [husband] wanted to stop.

Lucy coped with this career interruption by returning to full-time paid work before retiring permanently at age 65 . 


\section{Conclusion and discussion}

Combining feminist political economy and life-course perspectives, this study examines the impact of gendered life-course experiences on extended working in a UK cohort of early baby-boomer women. A strength of this study lies in its mixed-methods approach. Analysis of survey data provides insights into the size, relative contribution and direction of effect on extended working of a range of variables. Complex social realities and the role of human agency can be obscured by statistical analysis and qualitative methods allow us to better determine the extent of the effects of structure versus agency (Charlwood et al., 2014). Integration of the results from both analyses sheds light on both the 'what' and the 'why' of women's extended working among members of the same cohort. The powerful extrinsic motivation provided by the need to earn money captured in the qualitative data provides an explanation for associations in the quantitative data between extended working and both mid-life employment and mid and later-life marital status. The strong negative effect of mortgage-freedom on extended working (identified by Lain (2016)) is also supported here. The role of home ownership status in later-life economic activity is under-researched. However, it is likely to be particularly significant both for this cohort and those retiring over the next decade who have experienced rapid rises in home-ownership (Resolution Foundation, 2019).

Positive aspects of employment also motivate extended working. Women described paid work as central to their lives in ways which are perhaps considered typically 'male' (for example, as a source of social status and independence). However, qualitative data support the contention that lifecourse proximity to the labour market is frequently not reflective of a preference for paid work over unpaid caring (Finch, 2014). Apparent preferences require critical scrutiny to reveal the ways in which habit, low expectations and structural constraints deform choices and aspirations (Krekula and Vickerstaff, 2017, Nussbaum, 2003). Too often, women are placed into binary categories of 'work/career-centred' or 'family-centred' (Hakim, 2000). Moen (2005) employs the notion of a "glass corridor" of institutionalised rules and norms that constrain women's choices throughout life. This 
vivid image well-illustrates the multiple constraints and challenges participants faced across the life course. Early-life narratives capture the extent to which women faced structural barriers to labour force participation that shaped both their opportunities and expectations. Among women in this study, the 'choice' of type of work and the 'choice' between paid work or family were structured by gender. Going against the grain of social expectations was challenging. Women in this cohort were the first to, apparently, want to 'have it all' (work and family); however 'having it all' was (and is) more frequently experienced as doing it all, with women juggling paid work and unpaid caring.

This study has a number of limitations. The quantitative sample size is relatively small, perhaps in part explaining the limited number of significant associations. However, the qualitative data allows a deeper exploration of associations not captured quantitatively. The number of interviews was limited by resource constraints; however, the qualitative data captured rich life-course narratives among women from a range of backgrounds. While attrition due to failure to follow-up is a potential weakness of any cohort study, the composition of the NTFS cohort is similar to that of the nationallyrepresentative English Longitudinal Study of Ageing (Steptoe et al., 2013). Despite these limitations, the findings provide lessons for policy makers. This cohort of women are currently transitioning to retirement and these findings shed light on their experiences. There are lessons too for future cohorts. There are few signs that the pace of social change has increased and if there ever was a gender revolution it has "stalled" (Pedulla and Thebaud, 2015: 117). The inequities faced by early baby-boomer women have proved stubbornly persistent. Men and women are still concentrated in different sectors of the workforce. The 'success story' of women's increased presence in the higher levels of the labour force is tempered by the fact that the number of women in 'already feminised' lower-level jobs has also increased (Court, 1995: 19). Generally low-paid caring and leisure jobs are dominated by women, while men dominate higher-paid management and senior official roles (Powell, 2019). Further, although the gender pay gap has reduced considerably over this cohort's life course, for the same work, women still earn less, on average, than men (Office for National 
Statistics, 2014). The "ideology of domesticity" (Crompton, 2006:10) that designates caring as primarily a woman's role, means it is still largely mothers who undertake the majority of childcare (Office for National Statistics, 2019). Although childcare is now more available than it was for young baby-boomer women, childcare costs present a major barrier to mothers' labour market participation (Harding et al., 2017). This study confirms the importance of flexible employment for women combing paid work with caring (Earl and Taylor, 2015). However, the UK labour market remains inflexible, largely to women's detriment (Trades Union Congress, 2014).

The gender revolution may, in part, have stalled due to challenging economic conditions. Life-course trajectories involving job insecurity, casualisation and precarious self-employment are now a common experience for women and men (Moen, 2011). For a real 'gender revolution' to occur policy must transform work to reflect the reality of women's (and increasingly, men's) lives rather than attempt to accommodate them within existing structures (Moen, 2011). Tentative steps are being made in this direction in the UK. For example, the new UK 'flat rate' pension aims to address women's pension disadvantage by reducing the number of qualifying years for a full state pension to 35. Nevertheless, the intersection of gender and socio-economic status creates its own set of challenges. For example, low-paid and part-time workers (still predominantly women) will continue to struggle to make the necessary National Insurance contributions that would enable them to receive the new flat-rate pension (Altmann, 2018). Finally, the increases in women's state pension age currently occurring in the UK provide a salutary lesson about the importance of paying attention to the life course. Since November 2018, women's state pension age has equalised with men's at age 65 , affecting women born after 1953. Like this study's women, many of these women face the same challenges of low pay and disrupted work. The relative rapidity of the pension changes means that many women are unprepared for retirement, leaving them at risk of poverty: unable to find employment and unable to retire (Altmann, 2018). The anger created by the failure of this policy to 
acknowledge the reality of people's lives (WASPI, 2018), underscores the importance of rejecting a 'one-size-fits-all' model of extended working.

While there are many paths to the outcome of extended working lives, not all paths are desirable (Timonen, 2016). Women 'choosing' to extend their working lives to avoid later-life poverty should not be judged a policy success. This study demonstrates the need for sociology to consider structural factors across the life course that encourage, prevent - or compel - women to extend paid employment beyond state-pension age. To this end, there is a pressing need for the creation of 'joined-up' policies addressing gender inequalities across the spheres of education, employment, pensions and unpaid care (Ní Léime and Street, 2017).

\section{Acknowledgements}

I gratefully acknowledge the Newcastle Thousand Families Study members for their continued participation in the study. I also thank three anonymous referees for their constructive comments.

Funding

This work was supported by the Economic and Social Research Council [grant number: $\mathrm{ES} / \mathrm{J} 500082 / 1] /$ 


\section{References}

Altmann R (2018) Equal state pension ages but no pension equality for women. Available at: https://pensionsandsavings.com/equal-state-pension-ages-but-no-pension-equality-forwomen.

Beehr TA, Glazer S, Nielson NL and Farmer SJ (2000) Work and nonwork predictors of employees' retirement ages. Journal of Vocational Behavior 57(2): 206-225.

Byles J, Tavener M, Robinson I, Parkinson L, Smith PW, Stevenson D, Leigh L and Curryer C (2013) Transforming retirement: New definitions of life after work. Journal of Women and Aging. 25(1): 24-44.

Carpentieri JD and Elliot J (2014) Understanding healthy ageing using a qualitative approach: the value of narratives and individual biographies. In: Kuh $D$, Cooper R, Hardy R, Richards $M$ and Ben-Shlomo Y (eds) A Life Course Approach to Healthy Ageing. Oxford: Oxford University Press.

Charlwood A, Forde C, Grugulis I, Hardy K, Kirkpatrick I, Mackenzie R and Stuart M (2014) Clear, rigorous and relevant: publishing quantitative research articles in Work, Employment and Society. Work, Employment \& Society 28(2): 155-167.

Court G (1995) Women in the Labour Market: Two Decades of Change and Continuity. London, UK: The Institute for Employment Studies.

De Preter H, Van Looy D, Mortelmans D and Denaeghel K (2013) Retirement timing in Europe: The influence of individual work and life factors. Social Science Journal 50(2): 145-151.

Dingemans E, Henkens K and Van Solinge H (2016) Working retirees in Europe: individual and societal determinants. Work, Employment \& Society 31(6): 972-991.

Duberley $\mathrm{J}$ and Carmichael F (2016) Career pathways into retirement in the UK: linking older women's pasts to the present. Gender, Work and Organization 23(6): 584-599.

Earl C and Taylor P (2015) Is workplace flexibility good policy? Evaluating the efficacy of age management strategies for older women workers. Work, Aging and Retirement 1(2): 214226.

Fasbender U, Wang M, Voltmer J-B and Deller J (2015) The meaning of work for post-retirement employment decisions. Work, Aging and Retirement 2(1): 12-23.

Finch N (2014) Why are women more likely than men to extend paid work? The impact of workfamily life history. European Journal of Ageing 11(1): 31-39.

Flynn M (2010) Who would delay retirement? Typologies of older workers. Personnel Review 39(3): 308-324.

Ginn J, Street D and Arber S (2001) Women, work and pensions: International issues and prospects. Buckingham, UK: Open University Press.

Green J and Thorogood N (2014) Qualitative Methods for Health Research. London: Sage.

Hakim C (2000) Work-Lifestyle Choices in the 21st Century: Preference Theory. Oxford: Oxford University Press.

Hank K and Korbmacher JM (2012) Parenthood and retirement. European Societies 15(3): 446-461.

Harding C, Wheaton B and Butler A (2017) Childcare Survey 2017. London: Family and Childcare Trust.

Henkens K (1999) Retirement intentions and spousal support: A multi-actor approach. Journal of Gerontology: Social Sciences 54B(2): S63-S73.

Hokema A and Scherger S (2016) Working pensioners in Germany and the UK: quantitative and qualitative evidence on gender, marital status, and the reasons for working. Population Ageing 9(1-2): 91-111.

Holloway G (2005) Women and Work in Britain since 1840. London: Routledge.

Jacobs JC, Laporte A, Van Houtven CH and Coyte PC (2014) Caregiving intensity and retirement status in Canada. Social Science \& Medicine 102: 74-82.

Karpen RR (2016) Reflections of women's retirement. The Gerontologist 56(6): 1-7. 
Kojala E and Moen P (2016) No more lock-step retirement: Boomers' shifting meanings of work and retirement. Journal of Aging Studies 36: 59-70.

Krekula $C$ and Vickerstaff $S$ (2017) Theoretical and conceptual issues in the extended working lives agenda. In: Ní Léime Á, Street D, Vickerstaff S, Krekula C and Loretto W (eds) Gender, Ageing and Extended Working Life: Cross-national Perspectives. London: Policy Press.

Lain D (2015) Work Beyond Age 65 in England and the USA. In: Scherger, S (ed.) Paid Work Beyond Pension Age: Comparative Perspectives. Manchester: Palgrave Macmillan.

Lain D (2016) Reconstructing Retirement: Work and Welfare in the UK and USA. Bristol: Policy Press.

Loretto W and Vickerstaff S (2013) The domestic and gendered context for retirement. Human Relations 66(1): 65-86.

Mccarthy M (2016) Social science and married women's employment in post-war Britain. Past and Present 233(1): 269-305.

Miller FJW, Court SDM, Knox EG and Brandon S (1974) The School Years in Newcastle upon Tyne, 1952-62. Oxford: Oxford University Press.

Moen P (2005) Beyond the career mystique: "time in," "time out," and "second acts". Sociological Forum 20(2): 189-208.

Moen P (2011) From 'work-family' to the 'gendered life course' and 'fit': five challenges to the field. Community, Work and Family 14(1): 81-96.

Moen P and Roehling P (2005) The Career Mystique: Cracks in the American Dream. Lanham: Rowman \& Littlefield.

Ní Léime Á (2017) Older women public sector workers in Ireland: decisions about retirement timing. Journal of Women \& Aging 29(5): 392-404.

Ní Léime Á and Loretto W (2017) Gender perspectives on extended working life policies. In: Ní Léime Á, Street D, Vickerstaff S, Krekula C \& Loretto W (eds) Gender, Ageing and Extended Working Life: Cross-national Perspectives. London: Policy Press.

Ní Léime Á and Street D (2017) Gender and age implications of extended working life policies in the US and Ireland. Critical Social Policy 37(3): 464-483.

Nussbaum M (2003) Capabilities as fundamental entitlements: Sen and social justice. Feminist Economics 9(2/3): 33-59.

O'Rand AM (1996) The precious and the precocious: understanding cumulative disadvantage and cumulative advantage over the life course. The Gerontologist 36(2): 230-238.

OECD (2017) Pensions at a Glance 2017: OECD and G20 Indicators. Paris: Organisation for Economic Cooperation and Development.

Office for National Statistics (2013) Pension Trends: The Labour Market and Retirement, 2013 Edition. London: ONS.

Office for National Statistics (2014) Annual Survey of Hours and Earnings: 2014. London: ONS.

Office for National Statistics (2018) How do the post-World War baby boom generations compare? London: ONS

Office for National Statistics (2019) Labour Market Overview, UK: March 2019. London: ONS.

Pearce MS, Unwin NC, Parker L and Craft AW (2009) Cohort profile: The Newcastle Thousand Families 1947 Birth Cohort. International Journal of Epidemiology 38(4): 923-937.

Pedulla DS and Thebaud S (2015) Can we finish the revolution? Gender, work-family ideals, and institutional constraint. American Sociological Review 80(1): 116-139.

Pleau R and Shauman K (2013) Trends and correlates of post-retirement employment, 1977-2009. Human Relations 66(1): 113-141.

Powell A (2019) Women and the Economy. London: House of Commons Library.

Resolution Foundation (2019) Home ownership in the UK. London: UK.

Scherger S (2015) Paid Work Beyond Pension Age Comparative Perspectives. London: Palgrave Macmillan.

Spence J, Walton WS, Miller FJW and Court SDM (1954) A thousand families in Newcastle upon Tyne: An approach to the study of health and illness in children. Oxford: Oxford University Press. 
Steptoe A, Breeze E, Banks J and Nazaroo J (2013) Cohort profile: the English Longitudinal Study of Ageing. International Journal of Epidemiology 42(6): 1640-8.

Taylor P, Loretto W, Marshall V, Earl C and Phillipson C (2016) The older worker: identifying a critical research agenda. Social Policy and Society 15(4): 675-689.

Thurley D, Keen R, Mcinnes R and Mcguinness F (2018) Women and Pensions. London: House of Commons Library.

Trades Union Congress (2014) Age Immaterial: Women over 50 in the Workplace. London: TUC.

Vickerstaff S (2006) 'I'd rather keep running to the end and then jump off the cliff'. Retirement decisions: who decides? Journal of Social Policy 35(03): 455-472.

Vickerstaff S and Cox J (2005) Retirement and risk: The individualisation of retirement experiences? Sociological Review 53(1): 77-95.

Walters S (2005) Making the best of a bad job? Female part-timers' orientations and attitudes to work. Gender, Work and Organization 12(3): 913-216.

WASPI. (2018) Women Against State Pension Inequality. Available at: https://www.waspi.co.uk.

Wiggins RD, Higgs PFD, Hyde M and Blane DB (2004) Quality of life in the third age: key predictors of the CASP-19 measure. Ageing \& Society 24(05): 693-708.

Wildman JM, Moffatt S and Pearce MS (2018) Quality of life at the retirement transition: life course pathways in an early 'baby boom' birth cohort. Social Science \& Medicine 207: 11-18.

Josephine Wildman is a Research Associate in the Institute of Health and Society at Newcastle

University. Her research interests include life-course influences on unequal ageing. 
Table 1: Participant characteristics $(n=14)$

\begin{tabular}{|c|c|c|c|c|c|}
\hline Pseudonym & $\begin{array}{l}\text { Household social } \\
\text { class age } 49-51\end{array}$ & $\begin{array}{l}\text { Family status } \\
\text { history }\end{array}$ & $\begin{array}{l}\text { Occupational status } \\
\text { age } 62-64\end{array}$ & $\begin{array}{l}\text { Occupational status } \\
\text { age } 67-68 \text { (time of } \\
\text { interview) }\end{array}$ & $\begin{array}{l}\text { Self-defined age of } \\
\text { retirement from career } \\
\text { job }\end{array}$ \\
\hline Rachel* & IV or V & Married & Retired & Retired & 60 \\
\hline Emma* & IV or V & $\begin{array}{l}\text { Married } \\
\text { Children }\end{array}$ & Retired & Retired & 55 \\
\hline Catharine* & I or II & $\begin{array}{l}\text { Married } \\
\text { Children }\end{array}$ & Caring & Caring/retired & 60 \\
\hline Susan* & I or II & Single & Retired & Retired & 54 \\
\hline Clare* & IV or V & $\begin{array}{l}\text { Widowed } \\
\text { Re-married } \\
\text { Children }\end{array}$ & Working part-time & Working part-time & 60 \\
\hline Sally* & IV or V & $\begin{array}{l}\text { Widowed } \\
\text { Cohabiting } \\
\text { Children }\end{array}$ & Working full-time & Retired & 66 \\
\hline Lynne* & I or II & $\begin{array}{l}\text { Divorced } \\
\text { Children }\end{array}$ & Working full-time & Casual work & 60 \\
\hline Jennifer* & I or II & $\begin{array}{l}\text { Single } \\
\text { Children }\end{array}$ & Working full-time & Retired & 64 \\
\hline Alice* & III & $\begin{array}{l}\text { Divorced } \\
\text { Re-married } \\
\text { Children }\end{array}$ & Working part-time & Working part-time & 50 \\
\hline Julia* & I or II & $\begin{array}{l}\text { Divorced } \\
\text { Re-married } \\
\text { Children }\end{array}$ & Caring & Caring/retired & 60 \\
\hline Lucy* & I or II & $\begin{array}{l}\text { Widowed } \\
\text { Re-married } \\
\text { Children }\end{array}$ & Working part-time & Retired & 50 \\
\hline Sarah** & I or II & $\begin{array}{l}\text { Married } \\
\text { Children }\end{array}$ & Working part-time & Retired & 64 \\
\hline Judith** & III & $\begin{array}{l}\text { Married } \\
\text { Children }\end{array}$ & Working full-time & Retired & 62 \\
\hline Anne** & IV or V & $\begin{array}{l}\text { Married } \\
\text { Children }\end{array}$ & Working full-time & Retired & 63 \\
\hline
\end{tabular}

* Member of the NTFS cohort. Household social class, family history and occupational status at age

62-64 derived from survey data. Occupational status and retirement age derived from interview data.

**Spouse of a NTFS study member. Characteristics derived from interview data. 
Table 2: Descriptive statistics and results of multivariable logistic regression analysis of factors associated with women's paid employment at age 62-64 $(n=199)$

\begin{tabular}{|c|c|c|c|c|}
\hline & \multicolumn{4}{|c|}{ Multivariable logistic regression } \\
\hline & $N=(\%)$ & Average partial effects & $95 \% \mathrm{Cl}$ & p-value \\
\hline Long term illness age $49-51$ & $56(28.1)$ & -.032 & $-.147, .082$ & .579 \\
\hline \multicolumn{5}{|l|}{ Social class age $49-51$} \\
\hline Professional or managerial & $114(57.3)$ & Reference & & \\
\hline Intermediate & $58(29.2)$ & -.046 & $-.176, .083$ & .483 \\
\hline Routine or manual & $27(13.6)$ & -.009 & $-.162, .144$ & .912 \\
\hline \multicolumn{5}{|l|}{ Employment status age $49-51$} \\
\hline Employed full-time & $84(42.2)$ & Reference & & \\
\hline Employed part-time & $65(32.7)$ & -.127 & $-.265, .011$ & .072 \\
\hline Self-employed & $16(8.0)$ & -.004 & $-.237, .228$ & .972 \\
\hline Economically inactive & $34(17.1)$ & -.267 & $-.402,-.132$ & $<.001$ \\
\hline \multicolumn{5}{|l|}{ Pension scheme contributions } \\
\hline Occupational pension & $104(52.3)$ & Reference & & \\
\hline Private pension only & $28(14.0)$ & .017 & $-.148, .182$ & .839 \\
\hline No non-state pension & $67(33.7)$ & -.048 & $-.169, .073$ & .437 \\
\hline \multicolumn{5}{|l|}{ Owner-occupancy status age 62-64 } \\
\hline Own-outright & $146(73.4)$ & Reference & & \\
\hline Own mortgaged & $33(16.6)$ & .192 & $.030, .355$ & .020 \\
\hline Renting & $20(10.0)$ & .007 & $-.147, .161$ & .927 \\
\hline \multicolumn{5}{|l|}{ Marital status age 49-51 } \\
\hline Married & $161(80.9)$ & Reference & & \\
\hline Divorced & $28(14.1)$ & .176 & $-.001, .353$ & .052 \\
\hline Single (never married) & $10(5.0)$ & .022 & $-.203, .247$ & .847 \\
\hline \multicolumn{5}{|l|}{ Partner's economic activity age 62-64 } \\
\hline Economically-inactive partner & $104(52.3)$ & Reference & & \\
\hline Economically-active partner & $53(26.6)$ & .344 & $.197, .490$ & $<.001$ \\
\hline No partner & $42(21.1)$ & .206 & $.037, .375$ & .017 \\
\hline Children & $168(84.4)$ & .06 & $-.069, .188$ & .362 \\
\hline One (+) surviving parent age $62-64$ & $47(23.6)$ & -.04 & $-.154, .075$ & .499 \\
\hline
\end{tabular}

